\title{
Analytical study of cause and risk factors of severe anemia in third trimester of pregnancy at tertiary care center
}

\author{
Juhi Agarwal, Archana Meravi, Poorva Badkur*
}

Department of Obstetrics and Gynecology, Gandhi Medical College, Bhopal, Madhya Pradesh, India

Received: 01 July 2018

Accepted: 22 August 2018

\section{*Correspondence:}

Dr. Poorva Badkur,

E-mail: poorvadoc@gmail.com

Copyright: (C) the author(s), publisher and licensee Medip Academy. This is an open-access article distributed under the terms of the Creative Commons Attribution Non-Commercial License, which permits unrestricted non-commercial use, distribution, and reproduction in any medium, provided the original work is properly cited.

\begin{abstract}
Background: Anemia during pregnancy is a global public health challenge facing the world today. Among the South Asian countries, WHO estimate that India has the highest prevalence of anemia in pregnancy. Prevalence of anemia in pregnant Indian women is 49.7\%, against the global prevalence of 41.8\% (WHO 2008). In India, the prevalence of anemia is high because of ignorance, poverty, fewer intakes of iron, folic acid and food sources and gender bias significantly contribute to this high prevalence. Hence, this study aims to identify the risk factors and red cell morphological pattern that contribute to the presence and severity of anemia among pregnant women at the Sultania Zanana hospital, Gandhi Medical College Bhopal.

Methods: The present study was conducted in Department of Obstetrics and Gynaecology, Sultania Zanana Hospital, Gandhi Medical College, Bhopal, Madhya Pradesh, India. The study included all pregnant women at third trimester who was admitted at Sultania Zanana hospital, Bhopal from January 2016 to December 2016 having haemoglobin level $<7 \mathrm{gm} / \mathrm{dl}$. This is a Hospital- based Observational study. The sample size was calculated to be 500 .

Results: The following conclusion were drawn from this study. Poverty, early marriage, multiparity, poor nutrition, parasitic infections and lack of antenatal visits and antenatal care due to illiteracy and ignorance are probably the most important features responsible for severity of anemia. Maximum patients of anemia were in the age group of 21-35 Years. The majority of patients $(62.8 \%)$ were rural. Majority of cases (65.4) belongs to low-socioeconomic class followed by $(29.8 \%)$ belongs to middle socio-economic category. Most of the patients were multigravida (68.6\%) most of them came from poor and illiterate class of society $(74.2 \%)$ followed by women less than 20-year-old $(18.8 \%)$. Majority of patients had education level $(43.0 \%)$ below $10^{\text {th }}$ standard.

Conclusions: This study was undertaken to find out the various risk factors that contribute to the severity of anemia.
\end{abstract}

Keywords: Pica, Pregnancy, Severe anaemia

\section{INTRODUCTION}

Anemia during pregnancy is a global public health challenge facing the world today. It is estimated that around 2 billion people, $30 \%$ of the world population are affected with the majority coming from the developing world. ${ }^{1}$ Among the South Asian countries, WHO estimate that India has the highest prevalence of anemia in pregnancy. Prevalence of anemia in pregnant Indian women is $49.7 \%$, against the global prevalence of $41.8 \%$ (WHO 2008). ${ }^{2}$ In 2011 the highest prevalence of anemia was in children. The global prevalence of anemia for pregnant women was $38.2 \%$ and for all reproductive age was $29.4 \%$ (WHO GLOBAL DATABASE,2011). ${ }^{3}$ In India, the prevalence of anemia is high because of ignorance, poverty, fewer intakes of iron, folic acid and food sources and gender bias significantly contribute to this high prevalence. About half of all global maternal deaths due to anemia occur in South Asian countries, out 
of which India contributes to $80 \%$. In Asia, anemia (irrespective of severity) is the second leading cause of maternal death and accounts for $12.8 \%$ of maternal deaths independent of death due to postpartum hemorrhage. Despite these consequences, anemia continues to be a major challenge. There is little attention given at global and country levels to tackle this and even after a decade, deaths due to hemorrhage indirectly related to anemia is still remains the same. Many of the predisposing factors to anemia in pregnancy are preventable that may lead to women becoming pregnant with anemia; thus, there is still need for basic prevalence statistics to create awareness on the magnitude of anemia in pregnancy in our environment and also to formulate strategies to reduce its adverse health consequences in order to improve maternal health and reduce poor perinatal outcome. Hence, this study aims to identify the risk factors and red cell morphological pattern that contribute to the presence and severity of anemia among pregnant women at the Sultania Zanana hospital, Gandhi Medical College, Bhopal. The objective of the present study was to identify the risk factors that contribute to the presence and severity of anaemia.

\section{METHODS}

The present study was conducted in Department of Obstetrics and Gynaecology, Sultania Zanana Hospital, Gandhi Medical College, Bhopal Madhya pradesh, India. The study included all pregnant women at third trimester who was admitted at Sultania Zanana hospital, Bhopal from January 2016 to December 2016 having haemoglobin level $<7 \mathrm{gm} / \mathrm{dl}$. This is a Hospital- based Observational study. The sample size was calculated to be 500 .

\section{Inclusion criteria}

- All pregnant women at third trimester admitted at Sultania Zanana hospital.

\section{Exclusion criteria}

- All admitted cases of anemia came with antepartum haemorrhage $(\mathrm{APH})$ and shock, who were subjected to blood transfusion in last three months and with history of some diseases that may affect the result such as liver diseases, renal diseases, diabetes mellitus were excluded.

The study was approved by the medical ethical committee of Gandhi Medical College. A written consent was obtained from the participants after they had been informed with the objectives, benefit and expected outcome of the study.

\section{RESULTS}

In present study maximum number of cases $74.2 \%$ were in the age group of 21-35 years. followed by women less than 20-year-old (18.8\%). Only 35 (7.0\%) cases were more than 35 years old. In the present study we found that anemia was more prevalent in (43\%) pregnant women whose education level was below 10th standard followed by (32.2\%) below graduation level and (24.2\%) in ill-literate women.

Table 1: Demographic distribution of study subjects (anemic pregnant women) according to age.

\begin{tabular}{|lll|}
\hline Age groups & Number $(\mathbf{N})$ & Percentage $(\%)$ \\
\hline$<20$ year & 94 & 18.8 \\
\hline 21-35 year & 371 & 74.2 \\
\hline$>35$ year & 35 & 7.0 \\
\hline Total & 500 & 100.0 \\
\hline
\end{tabular}

In present study $65.4 \%$ pregnant women belongs to low socio-economic class followed by $29.8 \%$ belongs to middle socioeconomic category followed by only $4.8 \%$ belongs to high socioeconomic category.

Table 2: Demographic distribution of study subjects (anemic pregnant women) according to education level.

\begin{tabular}{|lll|}
\hline Education level & Number $(\mathbf{N})$ & Percentage $(\%)$ \\
\hline Ill-Literate & 121 & 24.2 \\
\hline Below $10^{\text {th }}$ & 215 & 43.0 \\
\hline Below graduation & 161 & 32.2 \\
\hline Graduate & 03 & 0.65 \\
\hline Total & 500 & 100.0 \\
\hline
\end{tabular}

The present study showed that severe anemia was more prevalent among rural population $62.8 \%$ as compare to urban population $37.2 \%$.

Table 3: Demographic distribution of study subjects (anemic pregnant women) according to socio economic status.

\begin{tabular}{|ll|l|}
\hline $\begin{array}{l}\text { Socio economic status } \\
\text { (SES) }\end{array}$ & $\begin{array}{l}\text { Number } \\
(\mathbf{N})\end{array}$ & $\begin{array}{l}\text { Percentage } \\
(\%)\end{array}$ \\
\hline High Income Class & 24 & 4.8 \\
\hline Middle Income Class & 149 & 29.8 \\
\hline Low Income Class & 327 & 65.4 \\
\hline Total & 500 & 100.0 \\
\hline
\end{tabular}

In the present study we found that anemia were seen more prevalent among women from joint family as compare to nuclear family.

Table 4: Distribution of study subjects (anemic pregnant women) according to locality.

\begin{tabular}{|lll|}
\hline Locality & Number $(\mathbf{N})$ & Percentage $(\%)$ \\
\hline Rural & 314 & 62.8 \\
\hline Urban & 186 & 37.2 \\
\hline Total & 500 & 100.0 \\
\hline
\end{tabular}


Out of 500 cases $60.2 \%$ were from joint family and $39.8 \%$ were from nuclear family. In present study $68.6 \%$ were multigravidas and $20.2 \%$ were grandmulti and $11.2 \%$ were primigravida. In present study anemia is significantly more common in multiparous women than grandmulti and primigravida.

Table 5: Distribution of study subjects (anemic pregnant women) according to type of family.

\begin{tabular}{|lll} 
Type of family & Number $(\mathbf{N})$ & Percentage $(\%)$ \\
\hline Nuclear family & 199 & 39.8 \\
\hline Joint family & 301 & 60.2 \\
\hline Total & 500 & 100.0
\end{tabular}

In present study most of the pregnant women had mixed dietary habits, $55.0 \%$ were non- vegetarian and $45.0 \%$ were vegetarian. In present study we found that out of 500 study subjects, 377 cases $(73.4 \%)$ had sterile sample, and 133 cases $(26.6 \%)$ had urinary tract infection.

Table 6: Distribution of study subjects (anemic pregnant women) according to gravid type.

\begin{tabular}{lll} 
Gravid type. & Number $(\mathbf{N})$ & Percentage $(\%)$ \\
\hline Primigravida & 56 & 11.2 \\
\hline Multigravida & 343 & 68.6 \\
\hline Grand Multi & 101 & 20.2 \\
\hline Total & 500 & 100.0 \\
\hline
\end{tabular}

Out of these 133 Cases, 101 cases (20.2\%) had asymptomatic bacteruria whereas 32 cases (6.4\%) had symptomatic bacteriuria.

\section{DISCUSSION}

\section{Age Distribution}

In present study maximum number of cases $74.2 \%$ were in the age group of 21-35 years. followed by women less than 20-year-old (18.8\%). Only $35(7.0 \%)$ cases were more than 35 years old. (Table 1).

In Fikir A et al, mean age of the pregnant women was 28 year. Nirmala B and Lahari $\mathrm{N}$ et al showed in her study that $68.4 \%$ cases were between $20-24$ years of age group. ${ }^{4,5}$ Ojengbede $\mathrm{SN}$ reported about two thirds of women were in the age group of 20-25 years. ${ }^{6}$ Anjum A et al, mean age of pregnant women was 26 year. ${ }^{7}$

A study from Karachi has reported a mean age of the pregnant women as 28 year. ${ }^{7}$ Lone at el and Idowu et al showed in his study that the prevalence of anemia was higher in 17-30 years age group. ${ }^{8,9}$ Ashok KP et al, showed in her study majority of pregnant women who was anemic were between 20-29 years. ${ }^{10}$ Kamath $\mathrm{R}$ and Pattanshetty SM et al, reveals that prevalence of anemia in pregnant women was $55.9 \%$ in the age group of $15-49$ years. $^{11}$

\section{Gravidity}

In present study $68.6 \%$ were multigravidas and $20.2 \%$ were grandmulti and $11.2 \%$ were primigravida. In present study anemia is significantly more common in multiparous women than grandmulti and primigravida (Table 6). Patra $\mathrm{S}$ et al revealed that $81 \%$ of their population in severely anemic groups were multiparas. ${ }^{12}$ Nirmala Devi Dr. B and Lahari $\mathrm{N}$ et al, showed that $65.24 \%$ women with severe anemia were multigravidas. ${ }^{5}$ Shrivastava Maneesha and Chanchalani Roshan et al, revealed in their study anemia was more prevalent in $2^{\text {nd }}$ gravida than primigravida only $6.3 \%$ were grandmultipara but in Idowu O.A et al, showed anemia was more prevalent among primigravida $80.6 \%$ than multigravida $(74.5 \%)(\mathrm{P}>0.05) .{ }^{9,13}$ In present study pregnancy interval for multiparas was found to be 1-2 years $(37.4 \%)$ which is in accordance with Alemayehu Bekele A, and Mekuria A et al study $(\mathrm{AOR}=3.1 ; 95 \% \mathrm{CI}$ : 6.01, 10.23). (Table 8). ${ }^{14}$ In Devi $\mathrm{N}$ et al, F Asrai et al, Mangla $M$ and Singla $D$ et al associated with rural residence.

\section{Socio-economic distribution}

In present study $65.4 \%$ pregnant women belongs to low socio-economic class followed by $29.8 \%$ belongs to middle socioeconomic category followed by only $4.8 \%$ belongs to high socioeconomic category (Table 3 ).

Devi $\mathrm{N}$ et al, showed in her study $88.65 \%$ severe anaemic women belongs to low socioeconomic category followed by $11.35 \%$ belongs to middle socioeconomic category. ${ }^{4}$ Noronha JA, Bhat $\mathrm{V}$ et al, revealed in his study that $65.2 \%$ of the pregnant women belonged to the low socioeconomic status. Rai $\mathrm{N}$ et al, studies showed that association of anemia with socioeconomic classes was found to be statistically highly significant $(\mathrm{p}=0.0066) .{ }^{15}$

\section{Type of family}

In the present study we found that anemia was seen more prevalent among women from joint family as compare to nuclear family. Out of 500 cases $60.2 \%$ were from joint family and $39.8 \%$ were from nuclear family (Table 5). Karaoglu L et al showed in his study that majority of anemic pregnant lived in nuclear families rather than extended families. ${ }^{16}$

\section{Education level}

In the present study we found that anemia was more prevalent in $(43 \%)$ pregnant women whose education level was below 10th standard followed by $(32.2 \%)$ below graduation level and $(24.2 \%)$ in ill-literate women (Table 2). Mihiretie $\mathrm{H}$ et al reported significantly higher prevalence of anemia among literates' women than illiterates and Kefiyalew F et al in South East Ethiopia observed that anemia was more common in literates (32\%) than illiterates $(25.3 \%)$. Rai $\mathrm{N}$ et al, Lokare PO et 
al and Panigrahi A et al studies found association with educational attainment of women. ${ }^{15-17}$ Whereas Kumar V et al did not found any significance association between anemia and educational status of the women.

\section{Dietary habits}

In present study most of the pregnant women had mixed dietary habits, $55.0 \%$ were non- vegetarian and $45.0 \%$ were vegetarian (Table 7). Mardones et al and Rizwan et al reveled in their study that high frequency of anemic patients in $3^{\text {rd }}$ trimester may be due to increased demand of micronutrients during this period in the background of poor dietary habits. ${ }^{7}$

Table 7: Dietary habits among anemic pregnant women.

\begin{tabular}{lll}
\hline Dietary habits & Number (N) & Percentage (\%) \\
Vegetarian & 123 & 24.6 \\
\hline Non-vegetarian & 377 & 75.4 \\
\hline PICA & & \\
Yes & 124 & 24.8 \\
\hline No & 376 & 75.2 \\
\hline Total & 500 & 100.0
\end{tabular}

Table 8: Inter pregnancy Interval among anemic pregnant women.

\begin{tabular}{|lll|}
\hline $\begin{array}{l}\text { Inter pregnancy } \\
\text { Interval }\end{array}$ & $\begin{array}{l}\text { Number } \\
(\mathbf{N})\end{array}$ & $\begin{array}{l}\text { Percentage } \\
(\%)\end{array}$ \\
\hline 1 Year & 203 & 40.6 \\
\hline 2-3 Year & 187 & 37.4 \\
\hline 4 Year & 110 & 22.0 \\
\hline Total & 500 & 100.0 \\
\hline
\end{tabular}

\section{Stool and urine culture and sensitivity}

The present study reveals that out of 500 study subjects 250 cases agreed for stool examination. Out of 250 cases 149 (59.6\%) had positive stool culture. 117 (23.4\%) had Helminth Infestation and $32(6.4 \%)$ had protozoal infestation. (50.0\%) cases not agreed for stool examination. In present study we found that out of 500 study subjects, 377 cases $(73.4 \%)$ had sterile sample, and 133 cases $(26.6 \%)$ had urinary tract infection. Out of these 133 Cases, 101 cases $(20.2 \%)$ had asymptomatic bacteruria whereas 32 cases $(6.4 \%)$ had symptomatic bacteriuria (Table 9).

Table 9: Urine culture and sensitivity among anemic pregnant women.

\begin{tabular}{|ll|l|}
\hline $\begin{array}{l}\text { Urine culture and } \\
\text { sensitivity }\end{array}$ & $\begin{array}{l}\text { Number } \\
(\mathbf{N})=500\end{array}$ & $\begin{array}{l}\text { Percentage } \\
(\%)\end{array}$ \\
\hline Asymptomatic bacteriurea & 101 & 20.2 \\
\hline Symptomatic bacteriurea & 32 & 6.4 \\
\hline Urinary tract infection & 123 & 24.6 \\
\hline Total & 256 & 51.2 \\
\hline
\end{tabular}

\section{CONCLUSION}

This study has highlighted the importance of considering maternal anaemia as an indicator of adverse pregnancy outcome. Therefore, to reduce the burden of this problem and related morbidity, measures need to be implemented at community level, which can prevent and treat anemia in adolescent girls and women. Anemia remains to be a problem with multifactorial causes hence, intervention only with iron and folic supplements is not adequate to tackle this problem. Therefore, there is a need to use multiple interventions, comprehensive approaches for addressing major preventable causes of anemia. Tackling this Problem alone in pregnancy will not be effective, however providing long-term preventive weekly iron supplements and dietary modifications beginning with adolescence may improve the haemoglobin level and prevent anemia in pregnancy. Hence, focus needs to be shifted from diet during pregnancy to diet during childbearing years especially in developing countries where adolescent pregnancies are common and adolescent health care is limited. Pregnant women must be counselled regarding detrimental effects of PICA on iron absorption. Present study is done at a tertiary care center where patients had come for institutional delivery. Home deliveries are still prevalent in the population. Maternal morbidities and mortalities are still under reported so what we are catering is just the tip of iceberg, the magnitude of problem may be beyond our expectation. Hence more efforts are required to promote institutional delivery and better fetal and maternal outcome near future.

\section{Funding: No funding sources \\ Conflict of interest: None declared}

Ethical approval: The study was approved by the Institutional Ethics Committee

\section{REFERENCES}

1. De Maeyer EM, Adiels TM The prevalence of anemia in the world. World Health Stat Q. 1985;38:302-16.

2. World Health Organization. The prevalence of anemia in women: A tabulation of available information. $2^{\text {nd }}$ ed. Geneva: WHO; 1992. Available at: $\quad$ http://whqlibdoc.who.int/hq/1992/WHO_ MCH_MSM_92.2.pdf.

3. Worldwide prevalence of anemia 1993-2005:WHO global database on anemia/Edited by Bruno de Benoist, Erin McLean, Ines Egli and Mary Cogswell. Available whqlibdoc.who.int/publications/2008/978924159665 7_eng.pdf

4. Nirmala D, Varalaxmi B, Jyothirmay T, Lahari N. Maternal outcome in pregnancy with severe anemia: Prospective study in a tertiary care hospital in Andhra Pradesh. J Dent Medi Sci. 2015;14:06-10.

5. District Level Household Survey on Reproductive and Child Health, India ,2002-2004. Available at: 
http://www.rchiips.org/pdf/rch2/

National-

Nutritional- Report-RCH-II. pdf. Accessed on 16may 2015.

6. Ojengbede OA, Okonkwo SN, Morhason-Bello IO. Comparative evaluation of haemoglobin estimation amongst pregnant women in Ibadan: Hemocue-B Haemoglobin analyzer versus haemiglobincyanide (Standard) method as the gold standard. African J Reproduct Health. 2008;12(2):153-9.

7. Anjum A, Manzoor M, Manzoor N, Shakir HA. Prevalence of anemia during pregnancy in district Faisalabad, Pakistan. Punjab Univ J Zool. 2015;30(1):15-20.

8. Mangla M, Singla D. Prevalence of anemia among pregnant women in rural India: a longitudinal observational study. Int J Report Contracept Obstet Gynaecol. 2016;5(10):3500-5.

9. Idowu OA, Mafiana CF, Dopu S. Anaemia in pregnancy: a survey of pregnant women in Abeokuta, Nigeria. African Health Sciences. 2005;5(4):295-9.

10. Lokare PO, Karanjekar VD, Gattani PL, Kulkarni AP. A study of prevalence of anemia and sociodemographic factors associated with anemia among pregnant women in Aurangabad city, India. Annals Nig Med. 2012;6(1):30.

11. Kamath R, Majeed JA, Chandrasekaran V, Pattanshetty SM. Prevalence of anemia among tribal women of reproductive age in Udupi Taluk, Karnataka. J Family Med Primary Care. 2013;2(4):345.

12. Patra S, Pasrija S, Trivedi SS, Puri M. Maternal and perinatal outcome in patients with severe anemia in pregnancy. Int J Gynecol Obstet. 2005;91(2):164-5.
13. Shrivastava M, Soni P, Sinha U, Chanchlani R. Study of hemoglobin levels in pregnant women and its various effects on pregnancy outcome. J Evol Med Dental Sci. 2014;3(11):2740-6.

14. Bekele A, Tilahun M, Mekuria A. Prevalence of anemia and its associated factors among pregnant women attending antenatal care in health institutions of Arba Minch Town, Gamo Gofa Zone, Ethiopia: a cross-sectional study. Anemia. 2016;2016.

15. Rai N, Nandeshwar S, Rai P. A study on magnitude of anaemia and its socio-demographic correlates among pregnant women in Sagar city of Bundelkhand Region, Madhya Pradesh, India. Int J Commun Medi Public Health. 2017;3(1):128-32.

16. Karaoglu L, Pehlivan E, Egri M, Deprem C, Gunes $\mathrm{G}$, Genc MF et al. The prevalence of nutritional anemia in pregnancy in an east Anatolian province, Turkey. BMC Public Health. 2010;10(1):329.

17. Kefiyalew F, Zemene E, Asres Y, Gedefaw L. Anemia among pregnant women in Southeast Ethiopia: prevalence, severity and associated risk factors. BMC Research Notes. 2014;7(1):771.

Cite this article as: Agrawal J, Meravi A, Badkur P. Analytical study of cause and risk factors of severe anemia in third trimester of pregnancy at tertiary care center. Int J Reprod Contracept Obstet Gynecol 2018;7:3975-9. 